Andrzej MAMCARZ

Aquaculture

\title{
AN ATTEMPT TO ASSESS EFFECTS OF ILLUMINATED CAGE LOCATION ON COREGONID CULTURE RESULTS
}

\section{PRÓBA OKRES̊LENIA WPEYWU LOKALIZACJI SADZÓW OŚ:VIETLONYCH NA WYNIKI PO-DCHOWU RYB GLĄBIELOWATYCH (COREGONIDAE)}

\author{
Chair of Fisheries, \\ Academy of Agriculture and \\ Technology, Olsztyn
}

\begin{abstract}
Results of cage rearing of the whitefish (Coregonus lavaretus $\mathrm{L}$.) and $C$. peled Gmel. obtained in the pelagic zone of the lake are better than those from the littoral where pressure of various parasites is strongly marked. Regardless of this trend, however, fish culture in cages placed in different lake zones should be regarded as a highly variable random process, its variability being a net result of both the variation in various environmental processes and interaction of different components of the ecosystem.
\end{abstract}

\section{INTRODUCTION}

The Polish method of rearing coregonid juveniles in cages, based on light-atracted natural food, presents a large potential for intensifying fish production in lakes. In view of diminishing success of the natural spawning in coregonids, the method - coupled with artificial spawning - offers a chance of obtaining considerable amounts of juvenile for stocking purposes. The cage method has been finding an ever-increasing application in cultures of a growing number of species (Żiljukas et al., 1977; Jäger and Nelleiı, 1980; Schlumpberger and Zieborth, 1981; Champigneulle et al., 1986). The studies published so far demonstrate a diverse nature of cage cultures in limnologically different lakes (Bryliński et al., 1979). Depending on a type of a reservoir, the cage output at the first 
stage of rearing ranges from 0.1 to $2.8 \mathrm{~kg} / \mathrm{m}^{3}$. Varying outputs occur subsequently; too, in the same lake (Mamcarz and Szczerbowski, 1984), which demonstrates the need to find solution optimal for a given reservoir used for fish cage cultures. Location of cages in a lake which is highly variable morphologically may exert somejeffect on fish production. To assess this effect, an attempt to culture Coregonus lavaretus $\mathrm{L}$. and $C$. peled $\mathrm{Gmel}$. in different zones of the same lake was made within 1978-1980. The present paper summarizes results of the experiment.

\section{MATERIALS AND METHODS}

The culture was located in Legińskie Lake (228.3 ha; $37.2 \mathrm{~m}$ maximum depth) situated in the upper reaches of the river Sajna (the Łyna-Pregoła catchment). Methods of rearing, environmental conditions in the lake, and research techniques are described elsewhere (Mamcarz and Szczerbowski, 1984; Szczerbowski and Mamcarz, 1984).

The $8 \mathrm{~m}^{3}$ cages were made of polyester tulle; initially, 1.0 and $1.8 \mathrm{~mm}$ mesh sizes were used to be changed after 5 months of culture to $5.5 \mathrm{~mm}$ mesh. Natural food was attracted with photocell-controlled cage illumination ( $24 \mathrm{~V} / 60 \mathrm{~W})$. A 24-h illumination
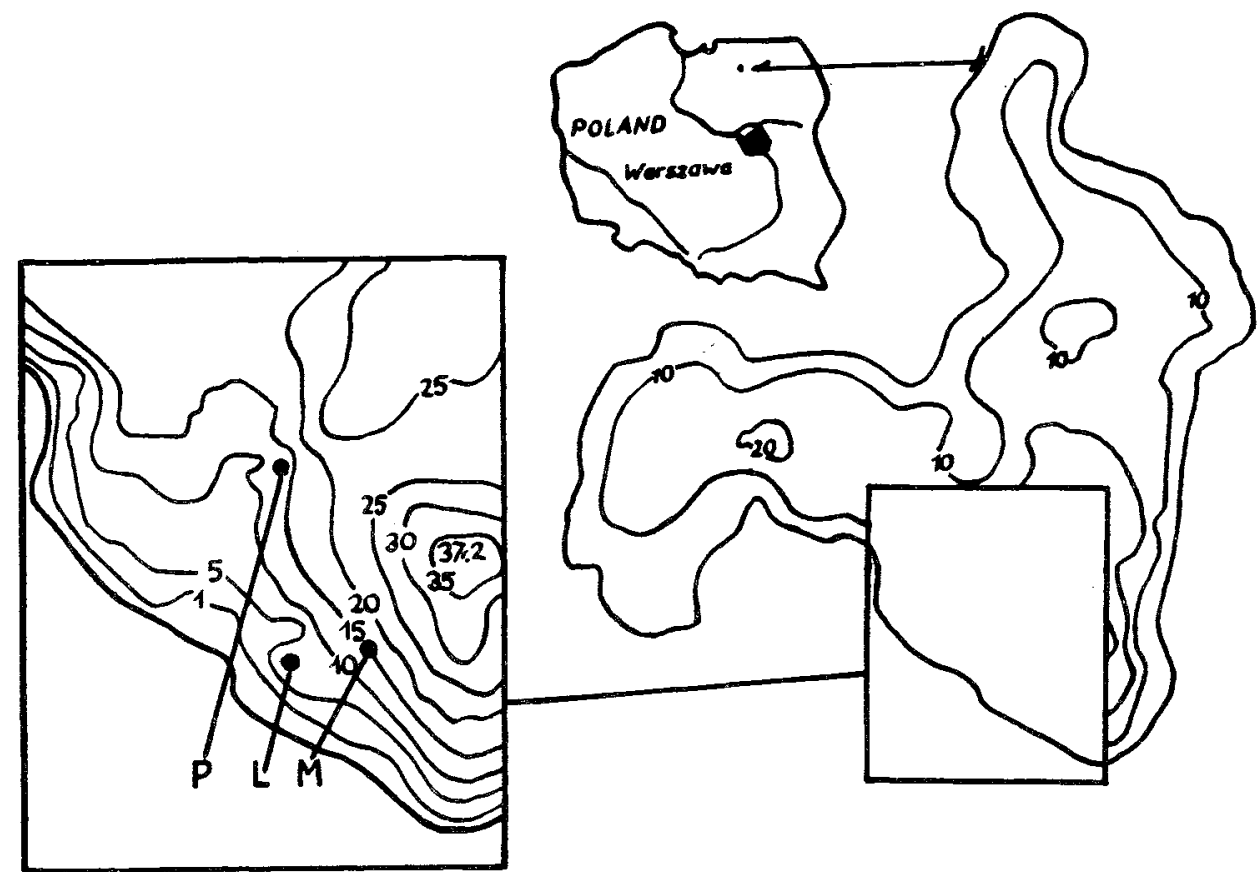

Fig. 1. Location of illuminated cages in Legińskie Lake (L, littoral site; $M$, middle site; $P$, pelagic site) 
Variability of effects of Coregonus Lavaretus L. rearing in cages in different zones of Legińskie Lake

(L - littoral; $\mathrm{M}$ - middle; $\mathrm{P}$ - pelagic)

\begin{tabular}{|c|c|c|c|c|c|c|c|c|c|c|}
\hline \multirow{2}{*}{\multicolumn{2}{|c|}{$\begin{array}{l}\text { No. of } \\
\text { cages }\end{array}$}} & \multicolumn{4}{|c|}{ Stocking } & \multicolumn{4}{|c|}{ Catch } & \multirow{2}{*}{$\begin{array}{c}\text { Survival } \\
(\%)\end{array}$} \\
\hline & & Date & $\begin{array}{c}\text { Number of } \\
\text { individuals } \\
\text { in cage }\end{array}$ & $\begin{array}{l}\text { Individual } \\
\text { length } \\
(\mathrm{mm})\end{array}$ & $\begin{array}{l}\text { Individual } \\
\text { weight } \\
\text { (g) }\end{array}$ & Date & $\begin{array}{l}\text { Number of } \\
\text { individuals } \\
\text { in cage }\end{array}$ & $\begin{array}{l}\text { Individual } \\
\text { length } \\
(\mathrm{mm})\end{array}$ & $\begin{array}{l}\text { Individual } \\
\text { weight } \\
\text { (g) }\end{array}$ & \\
\hline $\mathrm{L}$ & 4 & 31.05 .1978 & $1677-2860$ & $24.4-27.5$ & $0.086-0.154$ & 26.09 .1978 & $12-1567$ & $69.6-78.8$ & $2.37-4.24$ & $0.7-54.8$ \\
\hline M & 3 & 7.06 .1978 & $2765-4773$ & $25.1-27.6$ & $0.120-0.164$ & 26.09 .1978 & $896-2343$ & $60.4-70.8$ & $1.43-2.38$ & $32.4-54.6$ \\
\hline $\mathrm{P}$ & 4 & 31.05 .1978 & $2225-3517$ & 24.4 & 0.086 & 26.09 .1978 & $635-2145$ & $85.4-102.3$ & $4.44-7.99$ & $26.2-63.9$ \\
\hline $\mathrm{L}$ & 3 & 26.09 .1978 & $729-1567$ & $69.6-78.8$ & $2.37-3.28$ & 24.04 .1979 & $604-1041$ & $117.4-133.1$ & $14.6-19.9$ & $58.2-82.8$ \\
\hline M & 3 & 26.09 .1978 & $896-2343$ & $60.4-70.8$ & $1.43-2.38$ & 22.04 .1979 & $711-1439$ & $112.7-124.3$ & $12.6-18.0$ & $61.4-79.3$ \\
\hline$P$ & 4 & 26.09 .1978 & $635-2145$ & $85.4-102.3$ & $4.44-7.99$ & 24.04 .1979 & $229-902$ & $122.4-137.9$ & $16.5-23.3$ & $36.1-53.9$ \\
\hline $\mathrm{L}$ & 2 & 24.04 .1979 & $1031-1325$ & $125.2-127.0$ & $17.3-19.2$ & 13.07 .1979 & $887-1197$ & $142.7-147.1$ & $21.5-24.0$ & $86.0-90.3$ \\
\hline$M$ & 1 & 22.04 .1979 & 3442 & 121.4 & 16.1 & 13.07 .1979 & 2479 & 125.8 & 15.3 & 72.0 \\
\hline $\mathrm{P}$ & 2 & 24.04 .1979 & $811-1483$ & $129.1-130.9$ & $19.8-21.2$ & 13.07.1979 & $701-1329$ & $141.3-147.8$ & $24.3-28.5$ & $86.4-89.6$ \\
\hline $\mathrm{L}$ & 2 & 13.07.1979 & $870-1190$ & $142.7-147.1$ & $21.5-24.0$ & 28.09 .1979 & $714-969$ & $1519-155.3$ & $30.4-31.3$ & 82.1 \\
\hline M & 2 & 13.07 .1979 & $1210-1240$ & 125.8 & 15.3 & 27.09 .1979 & $504-572$ & $141.8-155.1$ & $22.8-30.6$ & $40.6-47.3$ \\
\hline $\mathrm{P}$ & 2 & 13.07.1979 & $686-1314$ & $141.3-147.8$ & $24.3-28.5$ & 28.09 .1979 & $481-835$ & $153.6-156.5$ & $32.4-35.1$ & $63.5-70.1$ \\
\hline $\mathrm{L}$ & 2 & 28.09 .1979 & $697-957$ & $154.9-155.3$ & $30.4-31.3$ & 5.05 .1980 & $233-318$ & $182.9-187.9$ & $61.2-62.9$ & $33.2-33.4$ \\
\hline M & 1 & 27.09 .1979 & 1035 & 149.2 & 27.2 & 5.05 .1980 & 721 & 185.2 & 58.0 & 69.7 \\
\hline $\mathrm{P}$ & 2 & 28.09 .1979 & $467-820$ & $153.6-156.5$ & $32.4-35.1$ & 5.05 .1980 & 54 & $193.4-193.6$ & $73.3-77.2$ & $6.6-11.6$ \\
\hline
\end{tabular}


Table 2

Efects of Coregonus peled Gmel. rearing in cages in different zones of Legińskie Lake ( $\mathrm{L}$ - littoral; $\mathrm{M}$ - middle; $\mathrm{P}$ - pelagic)

\begin{tabular}{|c|c|c|c|c|c|c|c|c|c|c|}
\hline & \multirow{2}{*}{$\begin{array}{l}\text { Nọ of } \\
\text { cages }\end{array}$} & \multicolumn{4}{|c|}{ Stocking } & \multicolumn{4}{|c|}{ Catch } & \multirow{2}{*}{$\begin{array}{c}\text { Survival } \\
(\%)\end{array}$} \\
\hline & & Date & $\begin{array}{l}\text { No. of } \\
\text { indiv. } \\
\text { in cage }\end{array}$ & $\begin{array}{l}\text { Indiv. } \\
\text { léngth } \\
(\mathrm{mm})\end{array}$ & $\begin{array}{l}\text { Indiv. } \\
\text { weight } \\
(\mathrm{g})\end{array}$ & Date & $\begin{array}{l}\text { No of } \\
\text { indiv. } \\
\text { in cage }\end{array}$ & $\begin{array}{r}\text { Indiv. } \\
\text { length } \\
(\mathrm{mm})\end{array}$ & $\begin{array}{c}\text { Indiv. } \\
\text { weight } \\
\text { (g) }\end{array}$ & \\
\hline $\mathrm{L}$ & 1 & 12.06 .1979 & 1000 & 26.9 & 0.13 & 28.09.1979 & 591 & 122.4 & 16.8 & 59.1 \\
\hline M & 1 & 12.06 .1979 & 1000 & 26.9 & 0.13 & 28.09 .1979 & 233 & 124.2 & 18.8 & 23.3 \\
\hline$P$ & 1 & 12.06 .1979 & 1000 & 26.9 & 0.13 & 28.09 .1979 & 796 & 127.5 & 19.1 & 79.6 \\
\hline $\mathrm{L}$ & 1 & 28.09 .1979 & 576 & 122.4 & 16.8 & 5.05 .1980 & 63 & 147.5 & 28.3 & 10.9 \\
\hline M & 1 & 28.09 .1979 & 213 & 124.2 & 18.8 & 5.05 .1980 & 49 & 161.1 & 55.8 & 23.0 \\
\hline $\mathbb{P}$ & 1 & 28.09 .1979 & 781 & 127.5 & 19.1 & 5.05 .1980 & 15 & 157.1 & 36.8 & 1.9 \\
\hline
\end{tabular}


was used during fish wintering under.ice. The cages, submerged to $3-5 \mathrm{~m}$, were mounted to floating platforme anchored at 3 different parts of the lake (1Fig. 1 ). The culture sites differed in their distance from shore and in depth. The littoral $(\mathbb{L})$, middle $(\mathbb{M})$, and pelagic (P) sites were located $50 \mathrm{~m}, 100 \mathrm{~m}$, and' $280 \mathrm{~m}$ off shore, respectively, their respective depths being $9,14.5$, and $13 \mathrm{~m}$.

Before the onset of the experiment (May), larvae of both species were kept at the middle site. In early June, cages at the three sites were stocked with $1600-4700$ inds/cage for $C$. lavaretuis and 1000 inds. (cage for Co peleot(Tábles 1 and 2). Throughout the culture period, the stocking densities diminished due to mortality and periodic (once or twice a month) removal of fish for examination. In the second year, the contents of some cages containing. C. lovaretus were pooled, thus reducing the number of cages at different sites.

Stocking density, was assessed by weight; the older fryswere counted, fish by fish, during consecutive phases of the experiment. Survival rate cit different phases and in different cages was determined as per cent survival relative to the stocking density at the beginning of each phase. Survival rate at each site was the mean for the respective cages, related to the initial stocking density at a site. Mean length and weight growth rates for each site were calculated as amean of values obtained from the respective cages.

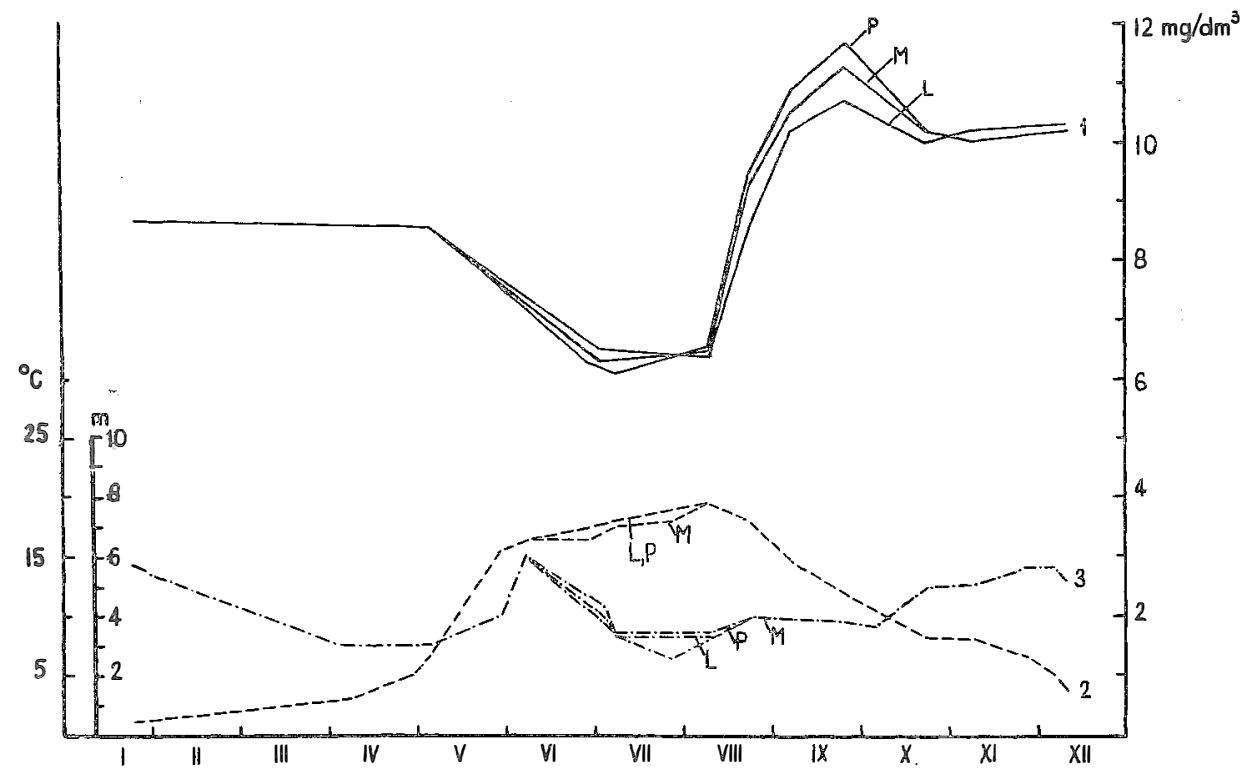

Fis 2 Changes in water oxygen content (1), temperature (2), and visibility (Secchi depthi) (3) within

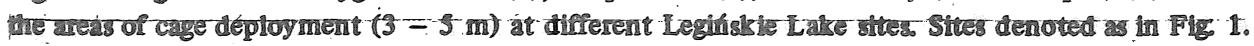


Environmental conditions at different sites

In 1978, water temperature, transparency, and dissolved oxygen content (DOC) showed little differences between the three sites (Fig. 2), the sites differing in temperature, transparency, and DOC by $0.2-0.4^{\circ} \mathrm{C}, 0.1-0,2 \mathrm{~m}$, and $0.2-0.4 \mathrm{mg} 0_{2} / \mathrm{dm}^{3}$, respectively. The pelagic site showed the lowest water temperature and DOC as well as the greatest Secchi depth.

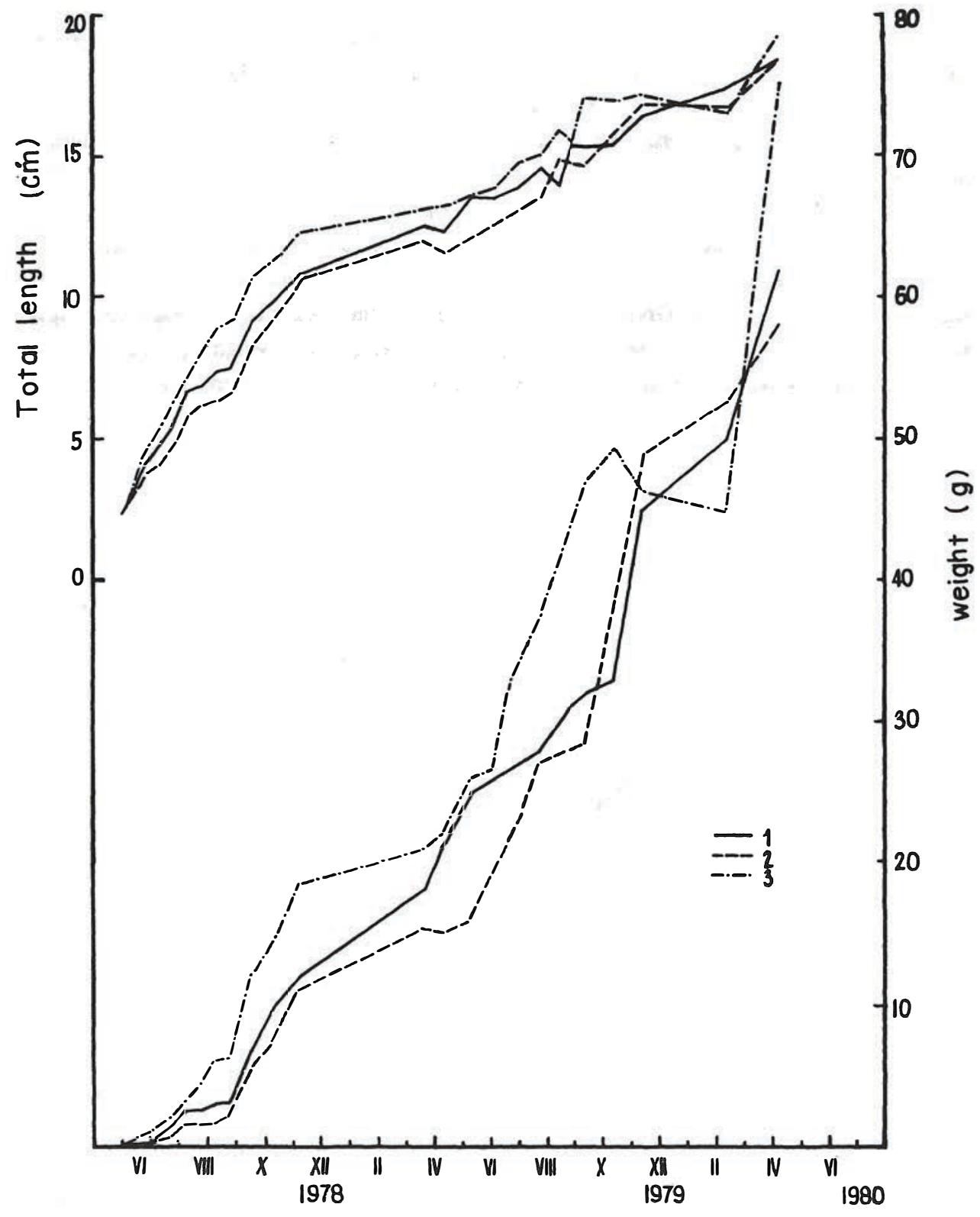

Fig. 3. Whitefish body length and weight growth in cages at different Leginskie Lake sites. 1, littoral site; 2 , middle site; 3 , pelagic site 


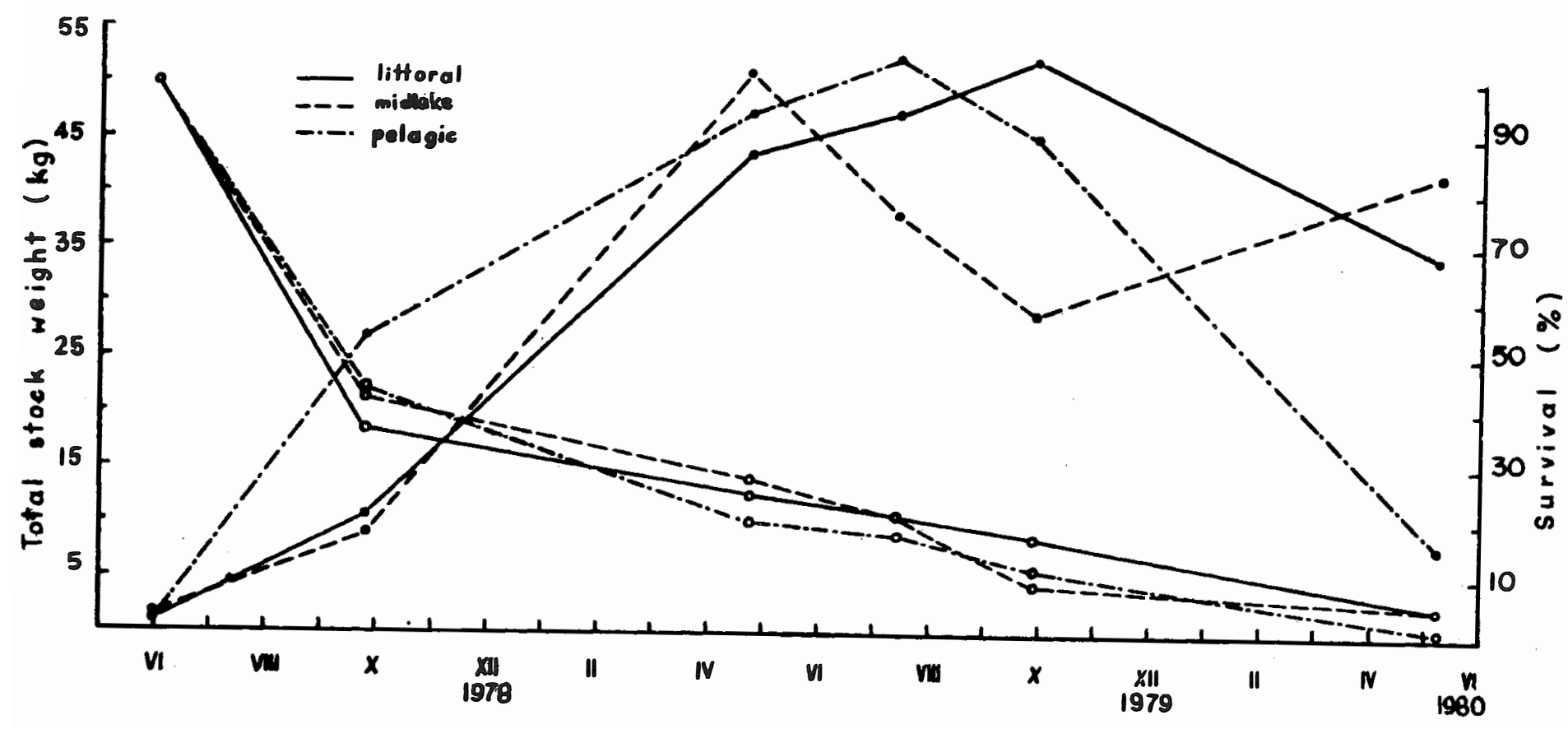

Fig. 4. Survival (o) and production (•) of whitefish in cages at different Legińskie Lake sites 


\section{Lavaretus culture in different lake zones}

The stocking material consisted of $C$. leveretus fry of varying size, obtained from the earlier May culture. Those individuals released to the pelagic site cages and to some of those at the littoral site weighed practically half the weight of the remaining ones (Table 1). In spite of that, the pelagic site fish soon proved to be the fastest growing ones and remained so throughout most of the time of the experiment (Fig.3). In late September 1978, the pelagic site $C$. Lovaretus attained mean weight and length of $5.7 \mathrm{~g}$ and $9.2 \mathrm{~cm}$, respectively. At that time the respective means for the littoral and middle site individuals were $3 \mathrm{~g} / 7.5 \mathrm{~cm}$ and $2 \mathrm{~g} / 6.5 \mathrm{~cm}$. The size of fish kept in different cages varied considerably (Table 1): inaviaual weights at the pelagic, littoral, and middle sites were observed to vary within $4.4-8.0 \mathrm{~g} .2 .4-4.2 \mathrm{~g}$, and 1.4-2.4 g, respectively.

The $C$. Invretuis survival rate during the summer 1978 stagnation was low regardless of the site (Fig 4). Mean survival of $37 \%$ was recorded at the itttoral site, slightly higher values (exceeding 40\%) boing obeerved at the middle and pelagic sites. The rate of survival was found to vary considerably between cages at each site, the survival rate ranges of Q.7-54.8\%, 32.4-54.6\%, and 26.5-63.9\% being recorded in the littoral, middle, and open lake zones, respectrvely (Table 1 ).

The to al fish biomass produced in cages is the outcome of interaction between growth and mortality in each caje. The pelagic site proved the best one in this respect since by the end of September the four cages at the site yielded more than $25 \mathrm{~kg}$ of juvenile 6 leveretus, i.e, more than the yield from 7 cages at the two remaining sites (Fig. 4).

Wintering of the fish tcook place during the "winter of the century" (1978/1979). Mean uir temperature over Docember - March was $-5.5^{\circ} \mathrm{C}$; the lake was ico-bound until mid-April. In spite of thdt, the fish grew fast, the between-sites growth rate differences being similar to those recorded the previous year. The pelagic site $C$. loviaretus igrew at the fastest rate and attainad more than $20 \mathrm{~g}$ mean weight and $12 \mathrm{~cm}$ mean length (Fig. 3). The fish at the remaining sites grew to slightly smaller sizes. The between-cages variability in fish stro was still observed, with the fish weight ranging within 16.5-23.3 g, $14.6-19.9 \mathrm{~g}$, and $12.6-18 \mathrm{~g}$ at the pelagic, littoral, and middle sites, respectively (Table 1). The stocking donsities levelled off as a result of wintering: in April 1979 the cages contuinod from 20.3 to $28.3 \%$ of their initial densities (Fiz 4). The total fish biomns procucod varted from 43.6 to $51 \mathrm{~kg}$ at the highest.

The next culture season and the second wintering brought no significant changes in fish growth at the three sites, with the pelagic site fish maintaining their fastest growth (Fig 3) until the termination of the experiment. The. ultimate fish growth rate and production in cages were adgificantly affected by survival rate in different cages and sites. It pas particalary evidont during the second wintering of the pelagic site fish with as little as 6.6-11.6\% of the Soptember stock aurvival (Table 1; Fig. 4).

\section{C peled culturo in dimerent lato zones}

Throe cages placed in different zones of the Logitskie Late were stocked in 1979 with C. peled whoce denafty was hilf that of $C$. Everetis (Table 2). In this case, too, better 
results of cage culture were obtained in the pelagic zone. By late September, the survival of $C$. peled at that site was 79.6\%, $19.1 \mathrm{~g}$ mean individual weight being recorded (Fig. 5). The survival rate and mean individual weight at the middle site were $23.3 \%$ and $18.8 \mathrm{~g}$, respectively. The poorest growth $(16.8 \mathrm{~g})$ was observed in the littoral, with $59.1 \%$ of the

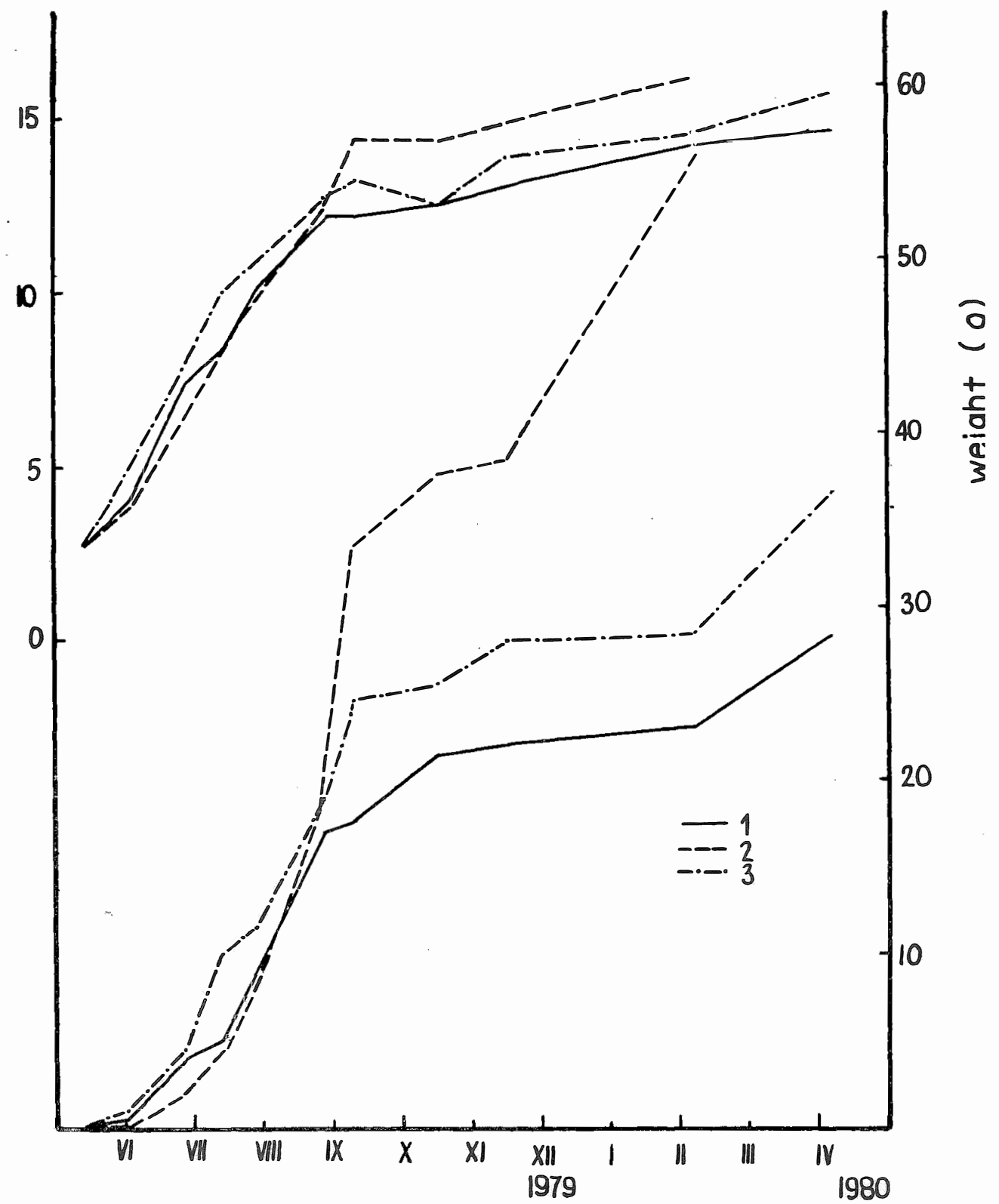

Fig. 5. Coregonus peled body length and weight growth in cages at different Legińskie Lake sites. Sites denoted as in Fig. 3. 


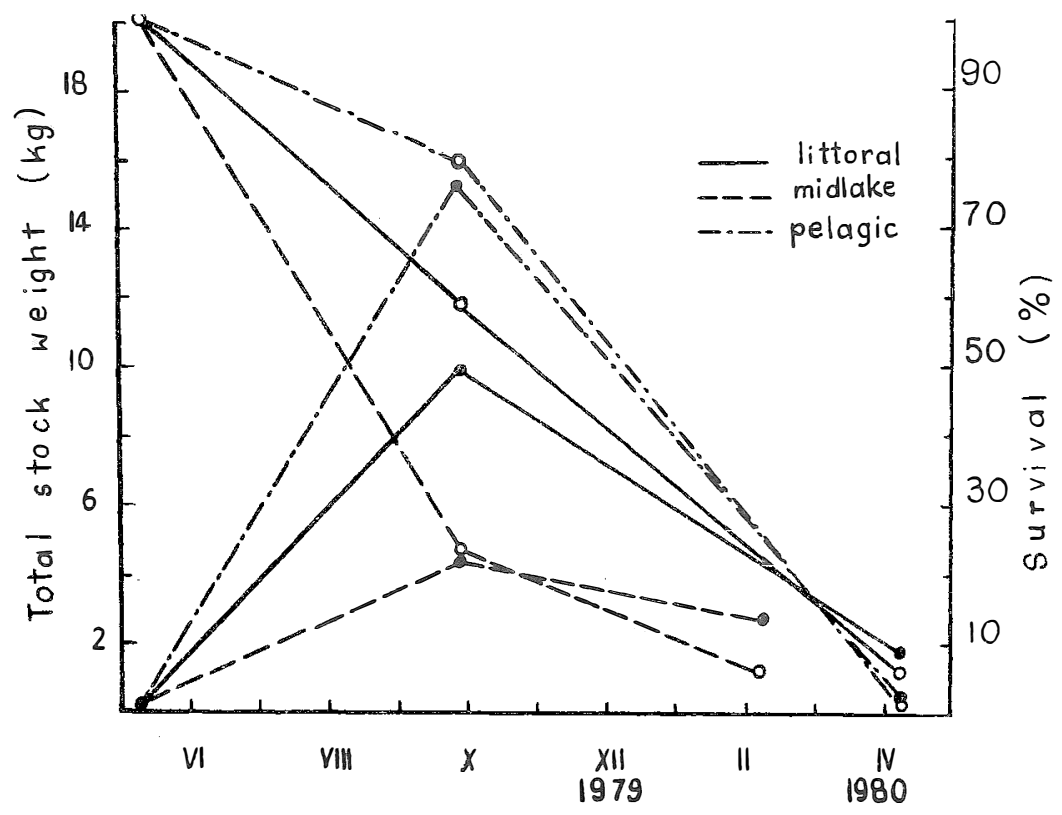

Fig. 6. Survival rate (o) and production ( $\bullet$ ) of $C$. peled in cages at different Legińskie Lake sites

fish survival (Table 2). Differences in growth and survival are reflected in.differentiated yields from 'cages at each site. In autumn 1979, the total $C$. peled biomass produced at the pelagic, littoral, and middle sites was about $16 \mathrm{~kg}, 10 \mathrm{~kg}$, and $4.5 \mathrm{~kg}$, respectively (Fig. 6).

In late autumn and winter 1979/1980, C. peled grew slowly, except for the middle site fish with half their initial stocking density remaining after earlier mortality, the low density triggering rapid growth of the survivors (Fig. 5). From 1.5 to $6.3 \%$ of the initial stock survived wintering under ice, the largest losses beingincurred by the pelagic site, as was also the case with $C$. lavaretus

\section{DISSCUSION}

In addition to selecting a lake for fish cage culture, a choice of cage location may be of a considerable importance. According to the recommendations in force at present (Brylînsla er al., 1975), cages shopld be located as far away from littoral vegetation as 
possible, macrophytes creating a habitat for gastrop ods and parasites. On the other hand, the distance off shore is limited by the length of electric wire.necessary for illumination. Thus the choice of location is a compromise between technological potential of the culturist and prophylactic precautions. In view of the lack of reports on effects of cage location, it was impossible to predict these effects on the culture under study.

The results obtained during the coregonid culture in cages placed in different parts of the Leginskie Lake show that the effects may be substantial. The total weight of C. lavaretus in the pelagic site cages was twice that produced at the remaining sites. A similar effect was obtained in the $C$. peled culture. Advantages of the pelagic site were evident both in terms of fish growth and survival, but concerned the first season of culture only. The results obtained for older fish kept in cages were highly variable and failed to confirm the a dvantages of placing the cages in the pelagic zone.

Concurrent studies on the health of fish kept at the three sites (Waluga, 1979, 1980) showed parasitic protozoans (Ichthyobodo necatrix Pinto, Cryptobia branchialis Nie, Ichthyopthirius multifilis Fouq., Trichodina sp., Chilodonella sp., Trichophrya sp.) to have played the major role in the survival of the two fish species, starting from the earliest stage of life. The protozoan invasion intensity was particularly high in the littoral, the invasion being delayed and much less intensive in the pelagic zone. In addition, algae and detritus were observed settle and sediment on the skin and gills of individuals of the two species culture (Waluga, 1980; Mamcarz and Worniałło, 1986), a phenomenon much stronger in the littoral zone, too, compared with the pelagic site. In late May (early June invasions of cercariae of Diplostomum spathaceum Rud. and D. clavatum Nord. were recorded. The highest intensity and incidence- of invasions were observed in the littoral; a lower parasitic pressure occurred at the middle site and the lowest in the pelagic zone. As a result of the strong invasions, all the fish in two cages died out twice in the littoral. On the other hand, the heaviest invasions of Proteocephalus cestode plerocercoids took place in the pelagic cages. Thus, effects of parasitic zonality on the cage-reared coregonids are clearly demonstrated by the fish health survey.

In this context it is interesting to consider the causes of the better growth parameters displayed by the fish kept in the pelagic zone. As shown by the dynamics of mortality in C. lavaretus and $C$. peled-stocked cages, the prevalence of the pelagic site did not result from any quantitative changes in the stocks. One may then conclude that the higher growth rate in the open lake area resulted from more abundant food resources present there. This conclusion, because of the lack of comparative data on zooplankton composition in different zones of the lake, can be a hypothesis only. The fragmentary data available on zooplankton density and composition at the littoral and middle sites (Table 3) show the abundance of food organisms to increase toward the shore. In addition, it is, however, difficult to reconcile the abundant pelagic food hypothesis with the analysis of find force and direction distributions. In view of the prevailing NW winds, the zooplankton is expected to be displaced toward the southern shores of the lalke, which has been in fact observed. The literature contains an ample body of data demonstrating wind effects on zooplankton distribution in lakes (Baker and Baker, 1976; 
Heaney, 1976; George and Edwards, 1976; Szlauer, 1976; Frempong, 1984).

On the other hand, noteworthy is the strongest Proteocephalus plerocercoid invasion at the pelagic site, the fact being indicative of a greater role of copepods (intermediate hosts) in the diet of coregonids kept in that zone. One may then get an impression that large zooplankton concentrations were formed in the pelagic zone, and that the better. growth of fish resulted from a more efficient consumption of copepods. Abundant literature on various groups of zooplankton (Brooks, 1957; Patalas, 1969; Starn, 1971; George and Edwards, 1973; Preissler, 1977) demonstrates that patchy, rather than zonal, distribution of zooplankton in water bodies is a rule. This is also the case in the Leginskie Lake (Dębowski, 1979, Mamcarz, 1988). Spatial structure (patchiness) of zooplankton has been subject to complex analyses and mathematical modelling procedures (Okubo, 1974; Dubois, 1975; Wróblewski and O'Brien, 1976). Patchiness is more and more frequently considered to be a result of habitat heterogeneity in various ways limiting distribution of living organisms (Hillbricht-Ilkowska, 1985). Under the circumstances then it seems that to assess the productive potential of cages placed in different lake zones is a highly complicated problem. It would be grossly erroneous to consider it solely in a simplistic manner as an effect of the distance from shore. In spite of the observed advantages of the pelagic site, growth and survival of coregonids in cages are highly variable chance phenomena, their variability resulting from interactions of different compartments of the ecosystem.

\section{REFERENCES}

Baker A.L., K.K. Baker, 1976: Estimation of planktonic wind drift by transmissometry. - Limnol. Oceanogro, 21 (3): 447-452.

Brooks J.L., 1957: The relationship between vertical distribution and seasonal variation of limnetic species of Daphnia。 - Verh. Internat. Verein Limnolo, 15: 684-690.

Bryliński $\mathbb{E}$. B. Uryn, J. Radziej, 1975:. Wychów materiału zarybieniowego koregonidów w oświetlanych sadzach jeziorowych. [Rearing of coregonid stocking material in illuminated lake cages]. - Oprac. brosz. IRS Olsztyn, 87: 1-10.

Bryliński E., J. Radziej, $\mathbb{B}$. Urym, 1979: Podchód wylęgu i narybku siei (Coregonus lavaretus L.) w oświetlonych. sadzach jeziorowy ch. [Rearing of Coregonus lavaretus $\mathbb{L}$. hatch and fry in illuminated lake cages]:- Rocz. Nauk roln., $\mathbb{H}-99-3: 55-77$.

Champigneulle A., M. Michoud, L. Ducret, G. Foussat, $\mathbb{H}$. Mudry, $\mathbb{D}$. Noel, G. Zegna, 1986: Étude de la production de preestivaux de Coregoné $i$ (Coregonus sp.) en cage éclairées immergées dans le Léman. - Bull. Fr. Pêche Piscic., 300: 1-12.

Dębowski Po, 1979: Próba określenia wpływu ryb jeziorowych na ilość zooplanktonu skorupiakowego w rejonie oświetlonych sadzów toniowych. [An attempt to assess effects of lacustrine fish on crustacean zooplankton abundance near illuminated cages]. - M.Sc. Thesis, Institute of Ichthyology and Fisheries, Academy of Agriculture and Technology, Olsztyn (Manuscript).

Dubois D.M., 1975: A model of patchiness for prey-predator plankton populations. - Ecol. Modelling, $1(1): 67-80$.

Frempong $\mathbb{E}_{0}, 1984:$ A seasonal sequence of diel distribution patterns for the planktonic dinoflagellate Ceratium hirundinella in a eutrophic lake. - Freshwater Biolo, 14(4): 401-421. 
George D.Gog R.W. Edwards, 1973: Daphnia distribution within Langmuir circulations. - Limnol. Oceanogr., 18: 798-800.

George $\mathbb{D}_{.} \mathbb{G}_{\text {. }}, \mathbb{R} . W$. Edwards, 1976: The effect of wind on the distribution of chlorophyll a and crustacean plankton in a shallow eu rophic reservoir. - J. Appl. Ecol., 13(3): 667-690

Heaney S.I.; 1976: Temporal and spatial distribution of the dinoflagellate Ceratium hirunainella O.F. Muller within a small productive lake. - Freshwater Biol, 6(6): 531-542.

Hillbricht-Ilkowska: A。, 1985: Współczesne kierunki badawcze w ekologii wód słodkich. III. Heterogenność środowiska wodnego, czynniki biotyczne a strategia życia organizmów. [Modern research trends in freshwater ecology. III. Heterogeneity of aquatic environment, biotic factors vs. organismic life strategy] - Wiad. Ekol, 31(3): 221-252.

Jäger $\mathbb{T}_{\text {。 }}$ W. Nellen, 1980: Die Erprobung einer polnischer Methode zum Vorstrecken von Maranen in Schleswig-Holstein. - Arb. Disch. Fisch-Verb., 30: 14-31.

Mamcarz A., 1982: Zmienność cech biometrycznych pelugi (Coregonus peled Gmelin, 1788) podczas jej chowu w sadzach jeziorowych. [Variability of biometric characteristics of Coregonus peled Gmelin, 1788 reared in lake cages]. Ph.D. Thesis Institute of Ichthyology and Fisheries, Academy of Agriculture and Technology, Olsztyn (Manuscript).

Mamcarz A., 1988: Czy sadzowy podchów ryb głąbielowatych zmienia strukturę zooplanktonu iv jeziorze? [Does the coregonid cage rearing change zooplankion structure in a lake? ] - Acta Acad. Agricult. Tech. Olst. 16:3-14.

Mamcarz A., J.A. Szczerbowski, 1984: Rearing of coregonid fishes (Coregonidae) in illuminated lake cages. $\mathbb{I}$. Growth 'and survival of Coregonus lavaretus $\mathbb{L}$. and Coregonus peled Gmel. - Aquaculture, 40: $135-145$.

Mamcanz $\mathbb{A}, \mathbb{E}$, Wormiatto, 1986: Effect of diatom blooms on the gills of whitefish (Coregonus lavaretus $\mathrm{L}_{0}$ ) reared in illuminated cages. - Aquaculture, $\$ 3: 1-5$.

Okubo A., 1974: Diffusion-induced instability in model ecosystems: another possible explanation of patchiness. Tech. Rep. Chesapeake Bay Inst. Ref., 74(3): 1-17.

Patalas K., 1969: Composition and horizontal distribution of crustacean plankion in Lake Ontario, J. Fish. Res. Board Can. 26: 2135-2164.

Preissler $\mathbb{K}_{\text {, }}$ 1977: Horizontal distribution and "avoidance of shore" by rotifers. Arch. Hydrobiol. Beih., 8: 43-46.

Schlumpberger W., G. Zieborth, 1981: Produktion von vorgestrecken Zandern in beleuchteten Gazekafigen. - Z. Binnenfish. DDR, 5: 143-144.

Starm ERA 1971: The horizontal-vertical distribution hypothesis: Langmuir circulations and Daphnia distributions. - Limnol Oceanogr., 16:453-466.

Szlauer L., 1976: Horizontal movement of the waters in the Insko Lake and its effects on biological phenomena in the lake. - Pol. Arch. Hydrobiolo, 23 (2): 175-188.

Szczerbowski J.A., A. Mamcarz, 1984: Rearing of coregonid fishes (Coregonidae) in illuminated lake cages. II. Environmental conditions during fish rearing. - Aquaculture, 40: 147-161.

Waluga $\mathbb{D}, 1979$ : Wyniki badań nad stanem zdrowotnym młodych stadiów ryb głąbielowatych - siei i pelugi w chowie sadzowym w sielawowym jeziorze Leginskim. [Results of studies on health of cage-reared juvenilè coregonids in Leginskie Lake. Work shop Proceedings "Technology of coregonid stocking material production in illuminated cages without artificial food"] - Olsztyn, 19-20.06. 1979.

Waluga $\mathbb{D} ., 1980$ : Ocena stanu zdrowotnego młodych stadiów ryb głąbielowatych w jeziorowym chowie sadzowym [Estimation of health status in young stages of coregonid fishes in lake cage culture] - Sprawozd. $z$ tem. bad. IRS-55/I, MS.

Wröblewslki J.S., J.J. O'Brier, 1976: A spatial model of phytoplankton patchiness - Mar. Biol, 35(2): $161 \mathrm{~m} 175$.

'Ëlijukas V.Ju., R.S. Volskis, V.V. Stankevicjus, 1977: Opyt vyrašcivanija molodi syrty (rybca)-w sadkach. - Ryb. choz., 7: 22-23.

Translated: Dr Teresa Radziejewsika 


\section{Andrzej Mamcarz}

\section{PRÓBA OKRES์LENIA WPŁYWU LOKALIZACJI SADZO̊W OS์WIETLONYCH NA WYNIKI PODCHOWU RYB GLĄBIELOWATYCH) (COOREGONIDAE)}

\section{STRESZCุZENIE}

W celu określenia wpływu lokalizacji sadzów oświetlonych na wyniki podchowu Coregonidae podjęto próbę wychowu narybku siei - Coregonus lavaretus L.) i pelugi (C. peled Gmel.) w trzech różnych miejscach $\mathrm{w}$ jeziorze Legińskim: na stanowisku litoralowym $(50 \mathrm{~m}$ od brzegu, głębokość jeziora $9 \mathrm{~m}$ ), środkowym (odpowiednio 100 i $14,5 \mathrm{~m}$ ) oraz pelagicznym (odpowiednio 280 i $13 \mathrm{~m}$ ). Stwierdzono zdecydowaną przewagę stanowiska pelagicznego, zarów no pod względem przeżywalności ryb jak i ich wzrostu. Od czerwca do września sieja uzyskała w pelagialu średnią masę $5,7 \mathrm{~g}$ przy długości $9,2 \mathrm{~cm}$, w litoralu odpowiednio $3 \mathrm{~g}$ i $7,5 \mathrm{~cm}$, a na stanowisku środkowym $-2 \mathrm{~g}$ i $6,5 \mathrm{~cm}$. Podchowywana w mniejszych zagęszczeniach peluga uzyskała w pelagialu masę $19,1 \mathrm{~g}$, na stanowisku środkowym 18,8 g i w litoralu 16,8 g. Zanotowano dużą zmienność wyników.w poszczególnych sadzach i porównywanych stanowiskach. Niezależnie od zarysowanej strefowości w oddziaływaniu pasoży tów na ryby i przewagi stanowiska pelagicznego, efekty produkcyjne w sadzach oświetlonych są zjawiskiem losowym o dużym zakresie zmienności, wynikającym $\mathrm{z}$ interakcji różnych elementów ekosystemu.

Author's address:

Received: 1987.12 .03

Dr. Andrzej Mamcarz

Akademia Rolniczo-Techniczna

Katedra Rybactwa

10-957 Olsztyn-Kortowo

Polska (Poland) 